\title{
ANALYSIS OF THE EFFECT OF MULTINATIONAL OIL COMPANIES ON THE CHIEFTAINCY INSTITUTION IN BAYELSA STATE, NIGERIA
}

\author{
OSUSU, O. 0 . \\ Department of History/Diplomacy, \\ Niger Delta University, Wilberforce Island, Bayelsa State. \\ Email: osusu60799@yahoo.com.
}

\begin{abstract}
This paper $x$-rayed the effect of multinational oil companies on the chieftaincy institution in Bayelsa state, Nigeria. It reports that the multinational oil companies have unfavourably affected the chieftaincy institution in Bayelsa State through their developmental efforts and the youths of their host communities. Finally, the paper posits that despite the attendant recurrent rebellion and protests by the youths against the chieftaincy institution, the latter is still in existence.
\end{abstract}

Key words: multinational oil companies, chieftaincy institution, Bayelsa State, Nigeria

\section{INTRODUCTION}

The Nigerian Bitumen Corporation, a German Company was issued a license in 1908 for oil exploration in Nigeria. But with the gust of the Fist World, the Company Oil exploration was suddenly brought to an end. However, it was only in 1937, that shell-D' arcy which later became shell BP., was granted permission to start oil exploration in the coastal area of the county. And Bayelsa State is central to the coastal area of the country. Nevertheless, the operations of shell D' arcy were equally brought to an abrupt end as the second World was broke out. It resumed operation in 1946 after the war had come to an end. Shell - B.P struck Oil in large commercial quantity in Oloibiri in Ogbia Local Government of Bayelsa State in 1956. Between 1956 and 2000, three Multinational Oil Companies established their base in Bayelsa State. The second is AGIP which has its operating base at Twon-Brass. The third major company was Texaco with its operating base at offshore close to Kuluama and Furupa in Bayelsa State. There after, several Oil Companies including chevron have been operating in Bayelsa State.

This oil production in Nigeria according to Udeme (2004) "has been a mixed bag of fortune and misfortune, of blessings and curses, depending on who is feeling what effect". He further opined that the existence of oil in the Niger Delta has remained a curse because concerted efforts by oil companies to provide palliatives for the harmful effects of their activities have not solved fundamental problems of the people. An import from Udeme (2004) argument is that, the multinational oil companies' activities affect all facets of their host communities. However, this author has not seen any study that attempts to show the influence of multinational Oil Companies on chieftaincy institution in Bayelsa State. The kernel of this paper, therefore, is to establish the effect of multinational oil companies on chieftaincy institution in Bayelsa State of Nigeria. To this end the paper sought to address the following: What is the meaning of multinational oil companies? What is the relationship between multinational oil companies and the chieftaincy institution in Bayelsa State? Does the multinational oil companies employ the youths as conduct pipe to affect the chieftaincy institution in Bayelsa State?

\section{The Meaning of multinational oil Companies}

Multinational oil companies are multinational company engaged in the business of oil exploration and exploitation. To understand the concept of multinational oil companies, it 
would be apropos to underpin the term multinational companies. Multinational companies are most often referred to as multinational corporations or transnational corporations. And Multinational Corporation according to Jhingan (1997)

"is a company, firm or enterprise with its headquarters in a developed country such as the United States, Britain, West Germany, Japan, etc. and also operates in other countries, both developed and developing. They are spread not only in the LDCs of Asia, Africa and Latin America, but also on the continents of Europe, Australia, New Zealand, and South America. They are engaged in mining, tea, rubber, coffee and cocoa plantations; oil extraction and refining, manufacturing for home production and exports, etc. Their operations also include such services as banking, insurance, shipping, hotels and so on. Thus like animals in the zoo, MNCs come in various shapes and sizes, perform distinctive functions differently and their individual impact on the environment"

However, the US Foreign Policy Encyclopedia (no date) hold that multinational corporations are corporations whose home offices are in one country yet possess considerable fixed investments in other counties. These investments might be in factories or warehouses, transportation or telecommunications, mining or agriculture. The activities of the multinational corporation according to Organization for Economic Cooperation and Development (1976) brings in positive contributions as well as creating problems. Therefore, it would not be out of place for the next sub-sections of this paper to find out the multinational oil companies positive contributions and problems their operations have created with regards to the chieftaincy institutions in Bayelsa State.

\section{Relationship Between Multinational Oil Companies and the Chieftaincy Institution}

The exploration and exploitation of oil by these companies had brought many benefits to the chieftaincy institution. In the first place the companies believe in maintaining cordial relationship with host communities. This explains why in part each company adopted a common strategy of improving upon the infrastructure of host communities as well as giving of financial stipend to the political heads of these communities. Available evidence on the nature of infrastructural development, as reported by Osusu (2001) reveals that both SPDC and AGIP have far exceeded TEXACO (see table below). Shell petroleum Development Company (SPDC) for example has embarked on the construction of roads, classroom blocks, portable water, electricity, jetty, town halls, as shown in the table below.

Table 1: Community Projects by Oil Companies Operating in Bayelsa State.

\begin{tabular}{|c|c|c|c|c|}
\hline S/No & Oil company & Community & Project & Remarks \\
\hline & & Azagbene & Six Classroom Blocks & Completed \\
\hline$\cdot$ & & $\begin{array}{l}\text { Aghoro I } \\
\text { Aghoro II }\end{array}$ & $\begin{array}{l}\text { Classroom blocks } \\
\text { Micro-Loan Scheme } \\
\text { Electrification }\end{array}$ & $\begin{array}{l}\text { Completed } \\
\text { On going } \\
\text { On going }\end{array}$ \\
\hline
\end{tabular}


Journal of Agriculture and Social Research (JASR) VOL. 10, No. 1, 2010

Shell Petroleum

Development

Company

Peretoru

Angalaweigbene

Aleibiri

Anyamasa

Ofoni

Biseni

Ikarama

Zarama

Nedo-Agbia

Agge

Amatu

Brilabiri

Ezetu

Opolo
School building

Town Hall

Six Classroom Portable Water

School Building

Road

Water Scheme

Six Classroom

Road

School Building

Okolobiri Road

School Building

Electrification

Portable Water

Portable Water

Six Classroom Blocks

Town Hall
Completed

----Do----

Completed

-----Do---

Completed

---Do-

Supplied

Completed

Completed yet to be commissioned

Completed

Still in

progress

Still under construction

Completed

Completed

Completed

Not

Completed

Not

Completed

Not

Completed

Still under construction

Completed 
Journal of Agriculture and Social Research (JASR) VOL. 10, No. 1, 2010

$\begin{array}{lll}\text { Igbogene } & \text { Road } & \text { Completed } \\ \text { Okutukutu } & \text { Town Hall } & \text { Completed } \\ \text { Amarata } & \text { School Buildings } & \text { Completed } \\ \text { Onopa } & \text { Six Classroom Blocks } & \text { Completed } \\ \text { Akenfa } & \text { Six Classroom Blocks } & \text { Completed } \\ & \text { Bridge (for foot only) } & \text { Completed } \\ \text { Biogbolo } & \text { Classroom Blocks } & \begin{array}{l}\text { Completed } \\ \text { Oporomo }\end{array} \\ & \begin{array}{l}\text { Electrification } \\ \text { Hospital }\end{array} & \begin{array}{l}\text { Completed } \\ \text { Under } \\ \text { Construction } \\ \text { Competed }\end{array} \\ & \text { Water School } & \text { Compl }\end{array}$

Angiama

Aguobiri

Water Scheme

Completed

Nembe

School Building

Completed

Road

----- Do ----

Electrification

Do ----

Brass

Portable Water

Completed

School Building

Completed 


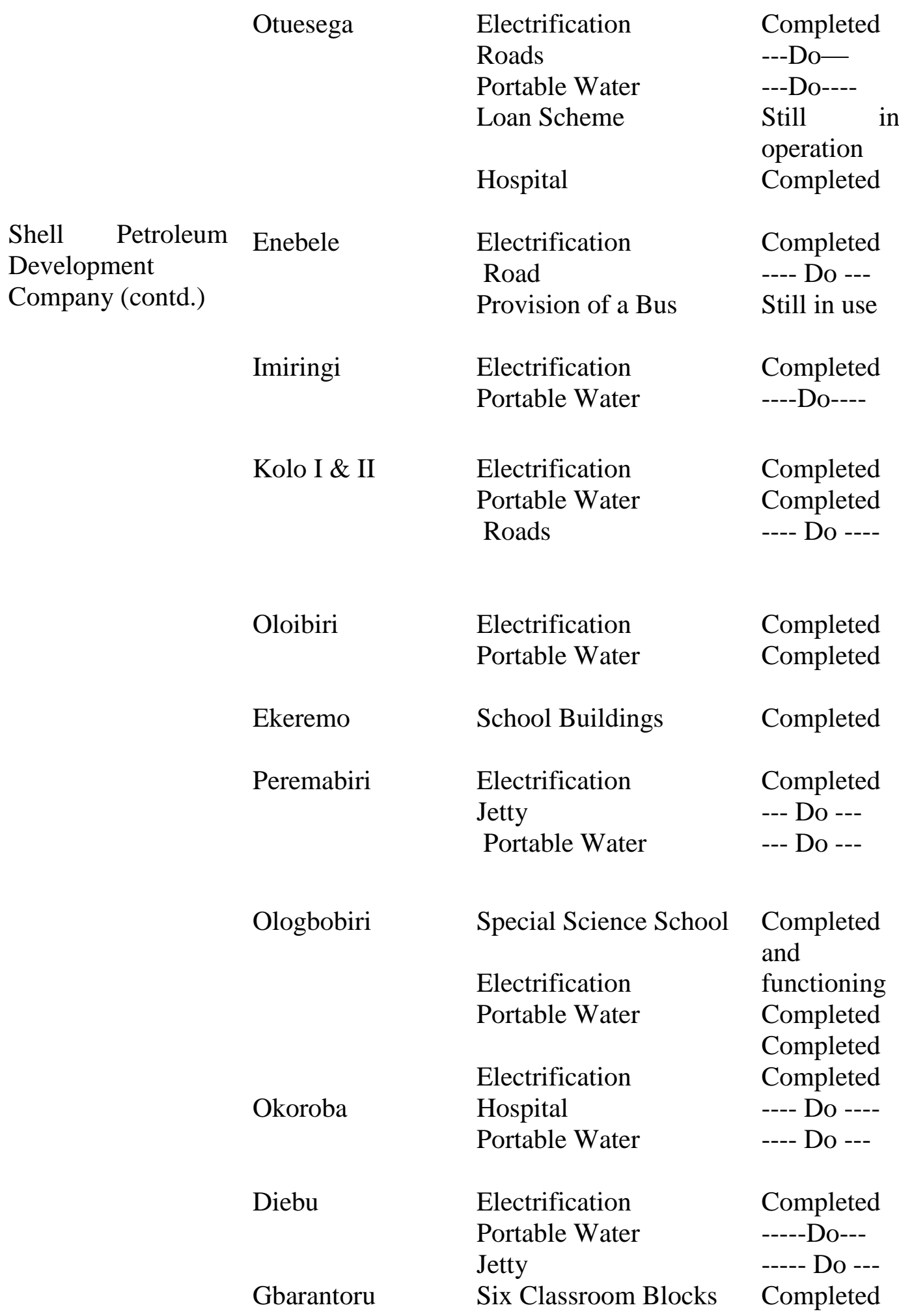




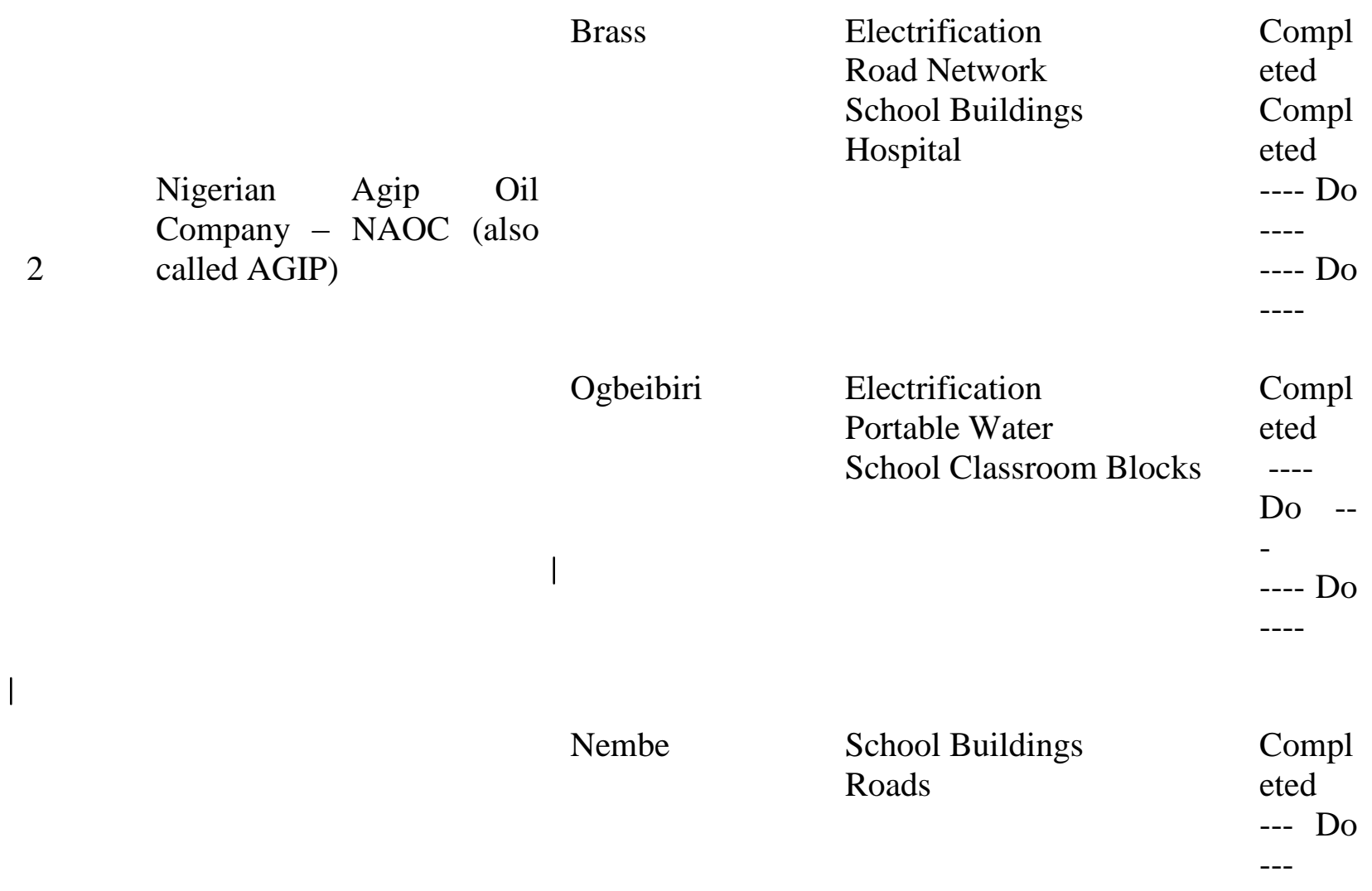

Okigbene

Tibidaba

Ologbobiri

Biseni
Portable Water

Jetty

Classroom Blocks

Six Classroom Blocks

Classroom Block

School Buildings

Jetty

Portable Water

Classroom Blocks Jetty

Classroom Blocks Health Center

Electrification

Roads

Classroom Blocks
Completed

---- Do ---

---- Do ---

Completed

Completed

Competed -

-- Do ---

--- Do ----

Completed

--- Do ---

Completed

Completed

Completed

---- Do ---

Completed 


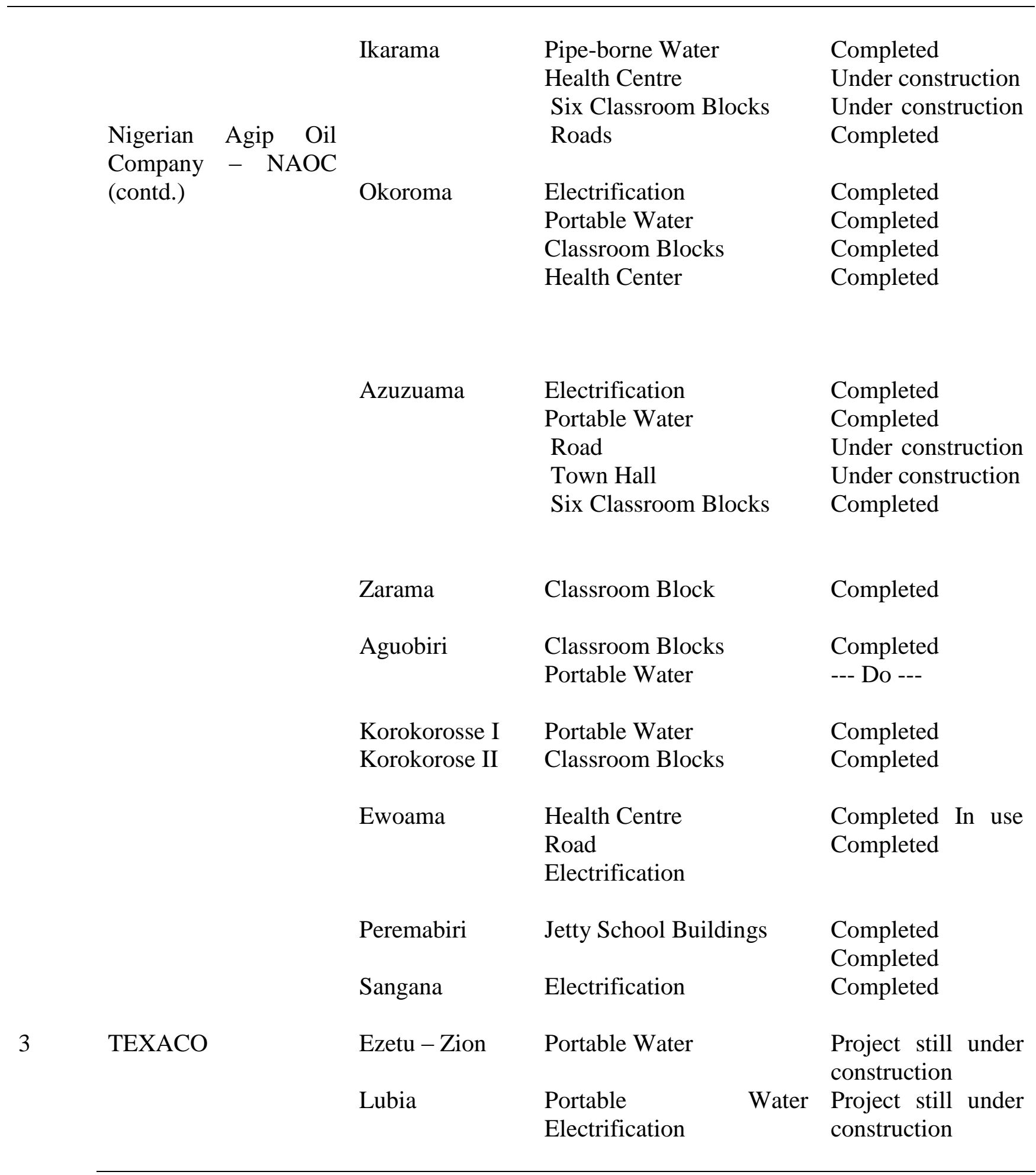

Source: Osusu (2001)

It is also worthy of note to mention the fact that all the Oil companies except TEXACO have scholarship programme going on in all the host communities. These scholarship programme extend from secondary schools to tertiary institutions. These companies also in their public relations did much towards the welfare of traditional rules in the state. For example, it is open secret that SPDC would give in addition to monthly allowance other financial gifts and 
gratification during Christmas and Easter seasons. Occasionally, these companies also give out bonuses to traditional rulers. Furthermore, SPDC and AGIP also encourage relationship among some prominent traditional rulers as well as allowances for those rulers who would provide security in safe-guiding company's pipeline within the domain of these traditional rulers.

Inspite of the numerous blessings the presence of the oil companies conferred on the chieftaincy institution in Bayelsa State, was one ugly development which if not checked can create enormous crises of confidence not only among the chiefs but also the citizenry. It would appear from the turn of event that the three major companies have been keen observers of political event in Bayelsa State. It should be pointed out that, one of the results of the creation of the Traditional Rulers Council in Bayelsa State was the expansion of the membership. This led to the Gabriel Okara Committee recommendation that consequently led to the proliferation of chieftaincy stools in which Baysela was saddled with over one hundred and fifty stools and/or chiefs. The oil companies saw this as a golden opportunity to exploit the inherent political crises as each community tried to produce several candidates for one stool. The oil companies would go into the fray by sponsoring rival candidates into one office. This situation created endless unrest within several host communities. In other words, the companies while fanning the embers of political crises would concentrate on their oil exploration with little or no distraction from the political authority of the communities. This was the weak-link in the political relationship between the oil companies and the chiefs in Bayelsa State. It was those weak-links which the youths of Bayelsa State exploited to further weaken the chieftaincy institution.

\section{Youth As Multinational Oil Companies Conduit Pipe to Affect Chieftaincy Institution.}

Another important segment of the population in the political history of Bayelsa State is a group of people generally referred to as youths. But operationally, this youth could be both male and female not above the age of forty years. For reasons of clarity, we shall employ this term to describe the crises of confidence which the youth have caused the chieftaincy institution in the state. Admittedly, some oil companies give out annual scholarship award, and it is the deserving members of the various youth organization which benefit from such awards.

That not withstanding, the youth have over the years been reacting violently to some aspects of the policies of the oil companies (Osusu 2001). We shall cite a few examples to illustrate this point. The first is in the way and manner which the scholarship forms are being distributed in the host communities. Instances exist in which the paramount ruler who is the custodian of this forms sells them to the highest bidder. Obviously, the youths consider this method as unjust as those qualified would loose an ample opportunity to further their education. This singular incident has caused much unrest in Bayelsa State. Secondly, each company regarded the paramount ruler of each community as the patron of employment. It became the duty of the paramount ruler to look for suitable candidates to be employed by each company. This is another opportunity for each ruler to make money from even nonindigenes seeking employment in the oil companies. The youths regard this as an unjust policy which excludes indigenes from such consideration. The third, is the contention between the chiefs and youths in the way and manner paramount rulers use various royalties which oil companies pay to them. In theory, each oil company is expected to pay so much money as royalties to paramount rulers, either on monthly or yearly bases. The paramount rulers are expected to use part of this royalty for the development of their communities. In practice, this is a far cry from the ideal. Paramount rulers rather use their royalty in fermenting political crises between different sections of their communities. The youths reject this outright and are reported to have stormed and burnt down palaces of those they consider 
to be recalcitrant. The above scenario was played out recently at Okutukutu, a town in the Epie - Atissa ethnic nationality. An informant: Chief Second Benson as reported by Bayelsa State Government (2001) narrated how "Shell Petroleum Development Company (SPDC) paid out a compensation of five hundred thousand naira, only, to the Okutukutu community through the paramount ruler the Obeneaken Chief Luther Abbey Amos. By the time he gave the money to his community he single handedly kept back one hundred thousand naira, only. The community asked why he brought only four hundred thousand naira, the chief replied that he had a right to the one hundred thousand".

The youth's reaction was obvious. They accused the chief of fraud and subsequently forced the deposition of the paramount ruler. In otherwords, the youths would prefer their community without a paramount ruler than having a fraud-star as a political head. The example of Epie-Atissa could be multiplied throughout the state.

\section{CONCLUSION}

From the analysis so far attempted, we can make the following inferences. The presence of oil companies and their policies of doling out financial benefits or allowances to traditional rulers have made some of these rulers become sub-agents to the oil companies. Hence, the recurrent rebellion and protest by the youths against that institution. In spite of the above ugly development surrounding the chieftaincy institution, the latter is still in existence. In other words, that institutions is a living organism and its growth and development or decay is dependent upon favourable or unfavourable development surrounding the institution.

\section{REFERENCES}

Bayelsa State Government. (2001). Local Government Administration Law (as amended). Yenagoa: Government Printer.

Jhingan M.L (1997). The Economics of Development and Planning. Delhi: Vrinda Publications (P) Ltd.

Organization for Economic cooperation and Development (1976) Guidelines For Multinational Enterprises, 15 I. L. M. 9 (1976). Retrieved on December 28, 2009 from http://www/.Umn.edu/humanrts/links/multinatguidelines.html

Osusu, O. O. (2001). Chieftaincy Institution in Bayelsa State: Change and Continuity, 1885 2000. An unpublished Ph.D dissertation, University of Calabar, Calabar.

Udeme, E. (2004). The Niger Delta and Oil Politics. Lagos: International Energy Communications Ltd.

US foreign Policy Enlyclopedia (No Date). Multinational Corporations. Retrieved on December 28, 2009 from http://www.answers.com/topic/ multinational-corporation. 